\title{
A arte perdida do beber católico
}

\section{The lost art of catholic drinking}

El arte perdido del beber católico

Laércio Fidelis Dias ${ }^{1}$

${ }^{1}$ Graduado em Ciências Sociais, Mestre e Doutor em Antropologia Social pela Universidade de São Paulo (USP). Atualmente é Professor

Doutor do Departamento de Sociologia e Antropologia e Programa de Pós-Graduação em Ciências Sociais, Vice-Coordenador do curso de Relações e Internacionais e Chefe do Departamento de Sociologia

e Antropologia, na Universidade Estadual Paulista (UNESP), campus Marília. Desenvolve pesquisa na área de Antropologia, com ênfase em Antropologia da Saúde e Médica, e Etnobiologia atuando nos seguintes temas: etnomedicina, itinerário terapêutico, transição da saúde, bebidas alcoólicas. E-mail: laercio@marilia.unesp.br 


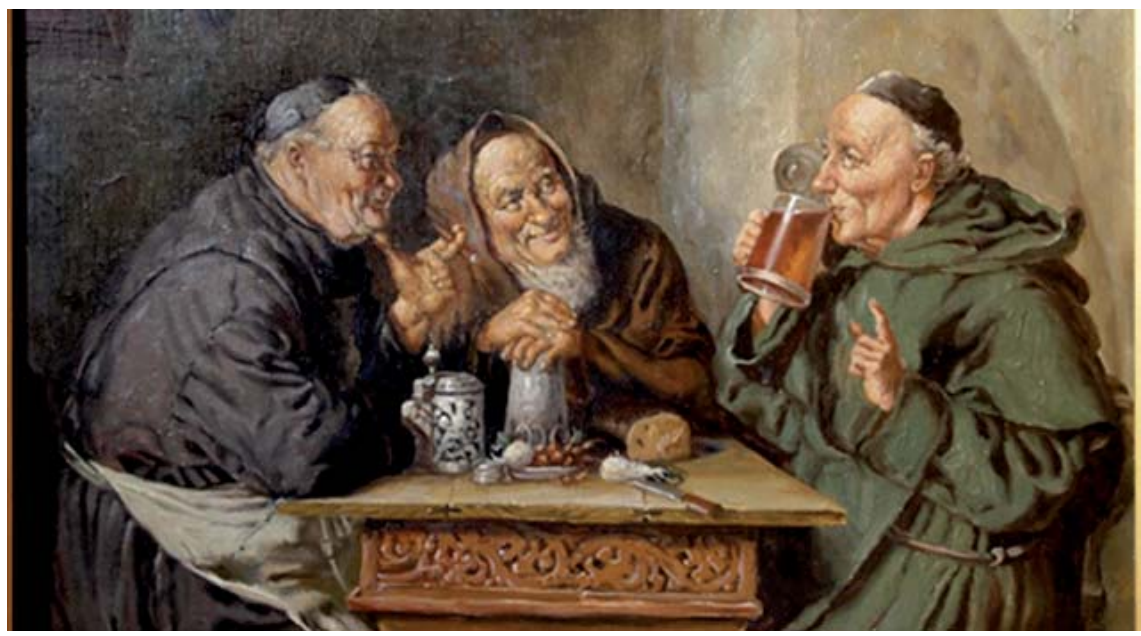

Há um estilo de beber Católico e outro estilo Protestante, e a diferença não é meramente a quantidade. Não disponho de dados científicos para sustentar minhas afirmações, tampouco disponho da compilação de estudos formais acerca da questão. Mas disponho de, digamos, um bom bocado de estudos informais que, para uma hipótese como a minha, é do melhor tipo.

Para começar, o que é um estilo católico de beber? É difícil definir, mas, a seguir, apresento um exemplo histórico. St. Arnold (580640), também conhecido como St. Arnulf de Metz, foi um bispo de Metz do século VII, que mais tarde tornou-se a França. Muito amado pelo povo, St. Arnold dizia ter pregado contra a água potável, o que àqueles dias poderia ser extremamente perigoso devido a sistemas de esgoto insalubres - ou, absolutamente, nenhum sistema de esgoto. Ao mesmo tempo, ele, com frequência, destacou os benefícios da cerveja, a quem é creditada a seguinte frase: "A partir do suor do homem e o amor de Deus, a cerveja veio ao mundo."

Palavras sábias que o rebanho de St. Arnold levou a sério. Após sua morte, o bom bispo foi sepultado em um mosteiro perto de 
Remiremont, França, onde aposentara. No entanto o seu rebanho sentia saudade e o queria de volta; então, em 641, tendo obtido a aprovação para exumar os restos mortais de St. Arnold, seu rebanho, em procissão, trouxe as exéquias de volta a Metz para enterrá-las na Basílica dos Santos Apóstolos. Ao longo do caminho, o rebanho sentiu sede e parou em uma pousada para um pouco de cerveja. Infelizmente, a quantidade de cerveja de que a pousada dispunha era suficiente para apenas uma caneca; mas todos tinham de tomar um pouco. Como conta a história, a caneca não secou até que todos tivessem tomado o seu gole.

Pois bem, não estou dizendo que o beber católico envolve milagres, ou que um milagre deve acontecer a cada vez que as pessoas se reúnem para beber. Mas boa cerveja-e um bom vinho para essa questão- é um pequeno milagre em si, sendo um presente de Deus para as suas criaturas, a quem ele ama. E, como GK Chesterton escreveu em Ortodoxia, "Devemos agradecer a Deus pela cerveja e pelo vinho, mas não beber demais." Em outras palavras, vamos mostrar a nossa gratidão a Deus pelo vinho e pela cerveja desfrutando-os, em bom ânimo e boa companhia, mas não apreciá-los em excesso.

Cada um deve julgar o que é excesso por si mesmo. No entanto é neste ponto que a principal diferença entre o beber católico e protestante revela-se. $\mathrm{O}$ estilo protestante de beber tende a ocorrer em um extremo ou outro: muito ou nada, sendo cada atitude uma reação a outra. Algumas pessoas, fartas, com razão, da justiça presunçosa dos abstêmios, reagem bebendo em excesso. Os abstêmios, por sua vez, horrorizados com os excessos dos bêbados habituais, intensificam a postura abstêmia. Não parece ocorrer a ambos os lados que suas atitudes não passam disso: reações contrárias, e não a solução. Se considerassem um pouco, veriam que há uma terceira via, que não envolve nem a embriaguez nem a abstinência, consistente com a vida cristã humana, honesta e saudável. 
E, nesse ponto, encontramos o beber católico. Ele é a terceira via, a maneira de se envolver numa atividade antiga, apreciada por todos, de camponeses e imperadores até mesmo Jesus. E mais uma vez, não se trata apenas de quantidade. Na verdade, creio que a principal diferença é o convívio. Quando amigos reúnem-se para tomar uma bebida, pode ser para comemorar ou lamentar. Entretanto deve-se sempre desfrutar da companhia de um e de outro (Sim, há um tempo e lugar para uma cerveja solitária, mas isso é a exceção.)

Por exemplo: as palestras nas Conferências anuais Chesterton não são elas próprias mais importantes do que as discussões dos participantes, mais tarde, acerca de algumas dessas mesmas palestras regadas à cerveja e a vinho (Ainda que tendemos a aderir à regra de ouro de Hillaire Belloc de, após a Reforma, evitar bebidas alcoólicas). Esses encontros, contudo, ocorrem entre palestras, durante as conversações - de fato, durante toda a noite- e normalmente caímos na cama, agradavelmente satisfeitos. Não posso imaginar uma Conferência Chesterton sem isso. $E$, ainda assim, também sei como seria prejudicial se tropeçássemos de volta para os nossos quartos rugindo de bêbados.

Evite cada extremo - é assim que se bebe como um católico. Essa é a arte de beber católica. Há muitos irmãos que consideram beber imoral, e há uma abundância de outros que pensam que beber deve terminar com grande intoxicação. Mas a abordagem equilibrada- católica- significa ter um bom tempo, uma boa risada, em algum momento um bom choro, mas sempre com alegria e gratidão pela generosidade de Deus, dando-nos maravilhas como cerveja e vinho. Lembre-se que a arte perdida de beber católica não pode permanecer perdida. 


\section{THE LOST ART OF CATHOLIC DRINKING}

Sean P. Daily

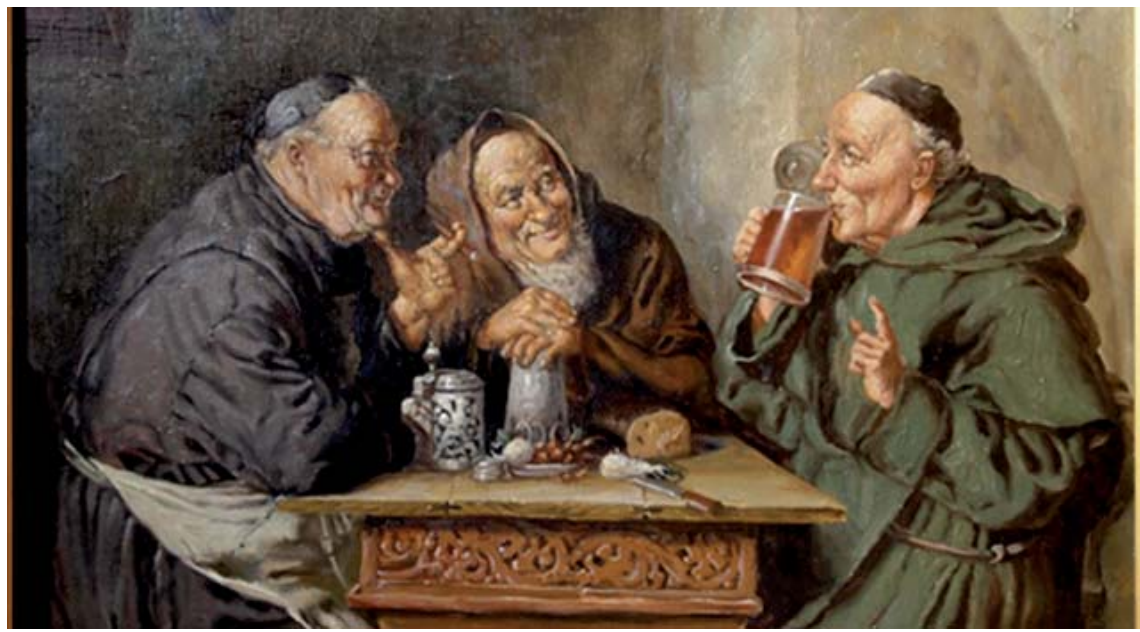

There is Protestant drinking and there is Catholic drinking, and the difference is more than mere quantity. I have no scientific data to back up my claims, nor have I completed any formal studies. But I have done a good bit of, shall we say, informal study, which for a hypothesis like this is probably the best kind.

To begin with, what is Catholic drinking? It's hard to pin down, but here's a historical example. St. Arnold (580-640), also known as St. Arnulf of Metz, was a seventh-century bishop of Metz, in what later became France. Much beloved by the people, St. Arnold is said to have preached against drinking water, which in those days could be extremely dangerous owing to unsanitary sewage systems - or no sewage system at all. At the same time, he frequently touted the benefits of beer and is credited with having once said, "From man's sweat and God's love, beer came into the world." 
Wise words, and St. Arnold's flock took them to heart. After his death, the good bishop was buried at a monastery near Remiremont, France, where he had retired. However, his flock missed him and wanted him back, so in 641, having gotten approval to exhume St. Arnold's remains, they carried him in procession back to Metz for reburial in the Basilica of the Holy Apostles. Along the way, it being a hot day, they got thirsty and stopped at an inn for some beer. Unfortunately, the inn had just enough left for a single mug; the processionals would have to share. As the tale goes, the mug did not run dry until all the people had drunk their fill.

Now, I'm not saying that Catholic drinking involves miracles, or that a miracle should occur every time people get together to imbibe. But good beer- and good wine for that matter - is a small miracle in itself, being a gift from God to His creatures, whom He loves. And as G. K. Chesterton wrote in Orthodoxy, "We should thank God for beer and burgundy by not drinking too much of them." In other words, we show our gratitude to God for wine and beer by enjoying these things, in good cheer and warm company, but not enjoying them to excess.

Just what constitutes excess is for each person to judge for himself. However, we now approach the main difference between Catholic drinking and Protestant drinking. Protestant drinking tends to occur at one extreme or another: either way too much or none at all, with each being a reaction to the other. Some people, rightly fed up with the smug self-righteousness of teetotalers, drink to excess. And teetotalers, rightly appalled at the habits of habitual drunkards, practice strict abstinence. It seems to occur to neither side that their reaction is just that: a reaction, and not a solution. If they considered it a bit, they might see a third way that involves neither drunkenness nor abstinence, yet is consistent with healthy, honest, humane Christian living. 
Here we encounter Catholic drinking. Catholic drinking is that third way, the way to engage in an ancient activity enjoyed by everyone from peasants to emperors to Jesus Himself. And again, it is not just about quantity. In fact, I think the chief element is conviviality. When friends get together for a drink, it may be to celebrate, or it may be to mourn. But it should always be to enjoy one another's company. (Yes, there is a time and place for a solitary beer, but that is the exception.)

For example: The lectures at the annual Chesterton conference are themselves no more important than the attendees later discussing those same lectures over beer and wine (we tend to adhere to Hilaire Belloc's rule of thumb, which is to avoid alcoholic beverages developed after the Reformation). These gatherings occur between talks, during talks - indeed, long into the night - and we typically fall into bed pleasantly stewed. I cannot imagine a Chesterton conference without this. And yet I also know how detrimental it would be if we all stumbled back to our rooms roaring drunk.

Avoid each extreme - that's how you drink like a Catholic. This is the art of Catholic drinking. There are plenty of our brethren who consider drinking somehow immoral, and there are plenty of others who think drinking must end with great intoxication. But the balanced approach - the Catholic approach - means having a good time, a good laugh, sometime a good cry, but always with joy and gratitude for God's generosity in giving us such wonders as beer and burgundy. Remember that, and the lost art of Catholic drinking may not remain lost.

Editor's note: This article was originally published by Crisis Magazine and is republished here with kind permission.

Image: Beer Drinking Monks (Piwo pijacy mnisi) by Arturo Petrocelli/ Wikimedia Commons 


\section{REFERÊNCIAS}

DAILEY, Sean P. The lost art of catholic drinking. Catholic Exchange. dez. 2013. Disponível em: <http://catholicexchange.com/catholic-drinking>. Acesso em: fev. 2017. 